\title{
Enzyme Activities Associated with Carbohydrate Synthesis and Breakdown in the Yeast and Mycelial Forms of Candida albicans
}

\author{
By F. W. CHATTAWAY, R. BISHOP, MARY R. HOLMES AND \\ F. C. ODDS \\ Department of Biochemistry, University of Leeds \\ AND A. J. E. BARLOW \\ Department of Dermatology, The Royal Infirmary, Huddersfield, Yorkshire
}

(Received 29 August 1972)

\begin{abstract}
SUMMARY
The mycelial and blastospore forms of Candida albicans have been grown under conditions in which the only environmental variable was temperature. The activity of phosphoglucose isomerase, phosphofructokinase and the first enzyme of the hexose-monophosphate pathway and the pathways for chitin and mannan synthesis has been determined in extracts at different times in the cell cycle. Phosphofructokinase has been partially purified from both forms and the effect of adenosine phosphates on its activity determined. In this yeast, concentrations of glucose-6phosphate, fructose-6-phosphate, ATP, ADP and AMP differed in the two growth forms and at different times in the growth cycle. L-Glutamine-D-fructose-6phosphate aminotransferase activity at concentrations of fructose-6-phosphate found in the cell was appreciably greater in mycelium than in blastospores. The metabolism of $\left[{ }^{14} \mathrm{C}\right]$ glucose through the hexose monophosphate pathway was low after 4 and $\mathrm{I} 8 \mathrm{~h}$ growth, and considerably increased at $\mathrm{IO} h$. The results support the concepts of a requirement for NADPH for cell division and suggest that control over the synthesis of chitin and mannan may, in part, be provided through control of the activity of phosphofructokinase by adenosine phosphates.
\end{abstract}

\section{INTRODUCTION}

A number of fungi are dimorphic, showing development of yeast and mycelial types of growth. The majority of those which are pathogenic for man show the yeast phase in infected tissues - for example, Histoplasma capsulatum, Blastomyces dermatitidis and Paracoccidioides brasiliensis - but in Candida albicans it is the mycelial form which is usually associated with growth within tissues. In all these organisms both morphological forms can be obtained during growth in vitro under suitable conditions and a number of environmental factors have been shown to affect development as well as the wall composition of the two forms. Thus in H. capsulatum, P. brasiliensis and B. dermatitidis the wall of the yeast form contained approximately three times as much chitin as the mycelial form (Domer, Hamilton \& Harkin, 1967; Kanetsuna, Carbonell, Moreno \& Rodriguez, I969); in Mucor rouxii the yeast-phase wall contained six times as much mannan as did the mycelial form (Bartnicki-Garcia \& Nickerson, 1962); in C. albicans after $18 \mathrm{~h}$ growth the mycelial-phase wall contained three times as much chitin as did the yeast phase and the distribution of mannose and glucose between wall fractions was different in the two forms (Chattaway, Holmes \& Barlow, 1968). The activity of enzymes involved in carbohydrate metabolism and the nature of polysaccharide components of the wall may also change as in $P$. brasiliensis where the yeast form 
contains an $\alpha$-I,3-glucan while the mycelial phase contains a $\beta$-I,3-glucan as well as the $\alpha$-isomer, the total glucan content remaining constant (Carbonell \& Kanetsuna, I966, 1970). The mechanism of control of the dimorphic change is uncertain but the above findings and the control exerted over morphogenesis of some strains of $M$. rouxii by hexoses (Bartnicki-Garcia, I968) suggests that it may be mediated through activities of enzymes associated with carbohydrate metabolism. The present paper is a study of the metabolism of $\left[{ }^{14} \mathrm{C}\right]-$ glucose by whole cells, the activities in extracts of $C$. albicans of glucose-6-phosphate and 6-phosphogluconate dehydrogenases, phosphoglucose isomerase, phosphofructokinase, L-glutamine-D-fructose-6-phosphate aminotransferase and phosphomannose isomerase, and the concentration of certain intermediates of metabolism at different times in the growth cycle and in both dimorphic forms. The aim was to explore possible relationships between differences in carbohydrate metabolism and morphological change.

\section{METHODS}

Organisms and growth medium. The strain (C-A-1) of Candida albicans (Robin) Berkhout used and the methods of maintenance and growth were as described by Chattaway et al. (1968). Medium B, adjusted to $\mathrm{pH}_{7.5}$ before autoclaving, was inoculated with $2 \times 10^{6}$ cells $/ \mathrm{ml}$, then incubated at $30{ }^{\circ} \mathrm{C}$ to obtain blastospores, or at $40{ }^{\circ} \mathrm{C}$ to yield mycelium. Other strains used were fresh isolates kindly given by Dr E. G. V. Evans of Leeds General Infirmary.

Estimation of the proportion of mycelium and blastospore forms produced. Mycelium production was measured by a modification of the method of Mardon, Balish \& Phillips (1969). Fungal suspensions were homogenized by five strokes of a Potter-Elvejhem groundglass homogenizer and cells counted in a haemocytometer. Cells of length up to three times the diameter of 'normal' blastospores (as judged visually) were defined as blastospores, those longer counted as mycelium. Mycelial strands were counted once for each haemocytometer square in which they appeared and thus some account was taken of the extent of mycelium formation. A minimum number of three full haemocytometer frames was counted for each culture. The mycelial count was expressed as a percentage of the total cell count and the agreement between replicate trials was better than $\pm 5 \%$.

Disruption of organisms and preliminary treatment of extracts. Blastospores were harvested by centrifugation at $2500 \mathrm{~g}$ for $20 \mathrm{~min}$ and washed three times with distilled water. Mycelium was obtained free from blastospores by repeated filtration through a sintered glass disc (porosity no. 3) with resuspension in water. After removal of samples for determination of dry weight of organism, the fungal mass was finally suspended in $50 \mathrm{~mm}$-potassium phosphate buffer, $\mathrm{pH} 6 \cdot 45$, unless stated otherwise. The organisms were disrupted by two passages through a French pressure cell at an internal cell pressure of $30000 \mathrm{lb} / \mathrm{in}^{2}$. Wall debris and any unbroken cells were removed by centrifugation at $10000 \mathrm{~g}$ for $10 \mathrm{~min}$. The supernatant was used for most enzyme assays and was diluted with the above buffer to a protein concentration of $2 \mathrm{mg} / \mathrm{ml}$ before use.

Enzyme assays. These were carried out at $\mathrm{pH} 6.45$ and 7.5 . The former was the intracellular $\mathrm{pH}$ in both morphological forms as determined by the method of Waddell \& Butler (1959), except that the cells were disrupted by sonication ( $8 \mathrm{~A}$ for $30 \mathrm{~min}$ in a Dawe sonicator) and not by homogenization. The values found at $\mathrm{pH} 7.5$ have only been recorded in specific instances. L-Glutamine-D-fructose-6-phosphate aminotransferase was assayed in a partially purified state prepared according to Kornfeld (1967), except that the concentration of glucose-6-phosphate was reduced from 5 to $0.5 \mathrm{~mm}$. The eluate from the Sephadex G-25 
was used for the assay, the final enzyme fraction being concentrated by using an Amicon Diaflo Ultrafiltration cell (PM Io membrane). The assay mixture $(3 \mathrm{ml})$ contained fructose6-phosphate $(54 \mu \mathrm{mol})$, glutamine $(36 \mu \mathrm{mol})$, sodium phosphate buffer, pH $6.45(0.2 \mathrm{M})$, EDTA $(3 \mu \mathrm{mol})$, dithiothreitol $(3 \mu \mathrm{mol})$ and enzyme extract; this mixture was incubated at $37{ }^{\circ} \mathrm{C}$ for $90 \mathrm{~min}$. The reaction was terminated by heating at $100{ }^{\circ} \mathrm{C}$ for $3 \mathrm{~min}$ then the glucosamine-6-phosphate produced was measured by the method of Ghosh, Blumenthal, Davidson \& Roseman (1960), except that half volumes were used.

All other enzymes were assayed at $30^{\circ} \mathrm{C}$ by coupling where necessary with appropriate enzymes and measuring changes in extinction at $340 \mathrm{~nm}$, the system reflecting changes in $\mathrm{NADH}$ or NADPH concentration. All values were corrected for endogenous activity. Glucose-6-phosphate and 6-phosphogluconate dehydrogenases and phosphoglucose isomerase were determined in a reaction mixture $(3 \mathrm{ml})$ containing glucose- 6 -phosphate or fructose-6-phosphate $(0.06 \mu \mathrm{mol})$ or 6 -phosphogluconate $(0.6 \mu \mathrm{mol})$, NADP $(0.6 \mu \mathrm{mol})$, $\mathrm{MgCl}_{2}(0.0 \mathrm{I} 5 \mu \mathrm{mol})$, phosphate buffer, $\mathrm{pH} 6.45$ or 7.5 (150 $\left.\mu \mathrm{mol}\right)$, and $0.3 \mathrm{ml}$ enzyme extract ( $2 \mathrm{mg}$ protein $/ \mathrm{ml}$ ). Phosphofructokinase was estimated according to Racker (I947) in $50 \mathrm{~mm}$-potassium phosphate buffer at $\mathrm{pH} 6.45$ or 7.6 ; for kinetic studies this enzyme was isolated from fungus grown for $\mathrm{I} 8 \mathrm{~h}$ and was partially purified by the method of Lindell \& Stellwagen ( 1 968), the eluate from Sephadex G-200 being used. The estimation of phosphomannose isomerase was based on the method of Gracy \& Noltmann (I968). The reaction mixture $(3 \mathrm{ml})$ contained mannose-6-phosphate $(4.5 \mu \mathrm{mol})$, NADP $(4.5 \mu \mathrm{mol}), \mathrm{MgCl}_{2}$ (0.42 $\mu \mathrm{mol}$ ), potassium phosphate buffer, pH 6.45 or 7.6 (I $19.5 \mu \mathrm{mol}$ ), glucose-6-phosphate dehydrogenase (20 units) and phosphoglucose isomerase ( 2 units).

Utilization of glucose by intact cells. The extent of degradation of glucose by the EmbdenMeyerhof-Parnas and hexose-monophosphate pathways and its assimilation by anabolic pathways was determined by the methods of Wang ( I972) with $\left[\mathrm{I}^{-14} \mathrm{C}\right]-,\left[6-{ }^{14} \mathrm{C}\right]$ - and $\left[\mathrm{U}-{ }^{14} \mathrm{C}\right]-$ glucose. Radioactivity was determined by using the Beckman LS 200 B liquid-scintillation system. The extent of glucose metabolism through the hexose-monophosphate pathways is given by

$$
G_{p}=\frac{G_{1}-G_{6}}{G_{\mathrm{T}}-G_{\mathrm{T}}}
$$

where $G_{p}$ is the fraction of glucose metabolized by the HMP pathway, $G_{1}$ and $G_{6}$ are ${ }^{14} \mathrm{CO}_{2}$ yields at time, $t$, after the metabolism of equal amounts of glucose labelled at $\mathrm{C}_{1}$ or $\mathrm{C}_{6}$ respectively, and $G_{T}$ is the total amount of each labelled substrate administered expressed as unity.

$G_{T^{\prime}}$ is the fraction of the administered labelled substrate which was used in anabolic processes. In determinations on resting yeasts, values for $G_{T^{\prime}}$ are usually negligible, but in using yeasts during the active phase of growth this value cannot be ignored. It has been estimated by measuring the evolution of ${ }^{14} \mathrm{CO}_{2}$ from $\left[\mathrm{U}-{ }^{14} \mathrm{C}\right]$ glucose over the $\mathrm{I} 2 \mathrm{~h}$ period and subtracting this value from the amount of ${ }^{14} \mathrm{C}$ added to the original medium, the previous experiments with specifically labelled glucose having established that uptake of the glucose was complete at this time.

Measurement of metabolic intermediates in extracts. Glucose-6-phosphate and fructose-6phosphate were determined by the method of Hohorst (1963), ATP by the method of Lamprecht \& Trautschold (I963) and ADP and AMP by the method of Adam (1963), all on the same perchloric acid extracts of fungus grown for 4 , I0 or $18 \mathrm{~h}$.

Enzyme activities. These have been expressed as $\mu$ moles of substrate transformed $/ \mathrm{min} / \mathrm{mg}$ dry wt of fungus in order to allow a true comparison to be made of activities in the two 


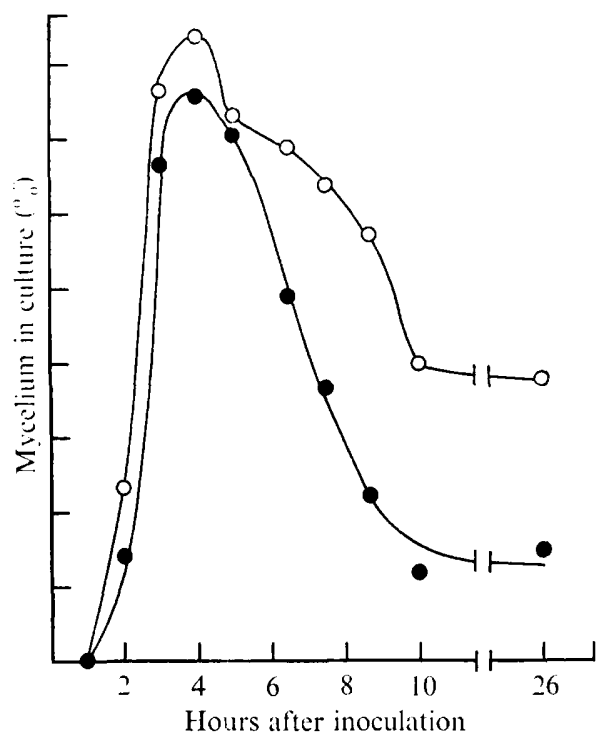

Fig. I. Variation of mycelium production with time. Medium B was inoculated with $2 \times 10^{\prime 2} \mathrm{cells} / \mathrm{m}$ l and incubated at $40^{\circ} \mathrm{C}$. Samples were removed to determine extent of mycelium formation at the times shown. $\mathrm{O}-\mathrm{O}$, Candida albicans strain $\mathrm{C}-\mathrm{A}-\mathrm{I} ;-\mathrm{C}$. albicans strain C-A-5.

Table I. Comparison of the weight of protein in extracts/unit cell dry wt in the blastospore and mycelial forms of Candida albicans

The differences between the mean values obtained from the two growth forms after different periods of growth are examined by Student's $t$ test. Number of determinations at least 15 for each time.

\begin{tabular}{|c|c|c|c|c|c|c|}
\hline \multirow{2}{*}{$\begin{array}{l}\text { Period of } \\
\text { growth } \\
\text { (h) }\end{array}$} & \multicolumn{4}{|c|}{ g protein $/ \mathrm{ml}$ extracts } & \multirow[b]{2}{*}{$t$} & \multirow[b]{2}{*}{$P$} \\
\hline & Blastospores & \pm S.E.M. ${ }^{*}$ & Mycelium & \pm S.E.M.* & & \\
\hline 0 & 0.1385 & 0.0133 & - & - & - & - \\
\hline 3 & 0.2848 & 0.0200 & 0.1297 & 0.0193 & $5 \cdot 39$ & $0.1 \%$ \\
\hline 4 & 0.3246 & 0.0197 & 0.2132 & 0.0242 & $3 \cdot 36$ & $1.0 \%$ \\
\hline 5 & 0.2902 & 0.0149 & 0.1375 & 0.0154 & $22 \cdot 20$ & $0.1 \%$ \\
\hline 10 & 0.2024 & 0.0128 & 0.1685 & 0.0244 & 0.99 & $5.0 \%$ \\
\hline 14 & 0.2228 & 0.0187 & 0.1994 & 0.0168 & 0.93 & $5.0 \%$ \\
\hline 18 & 0.2689 & 0.0191 & 0.1667 & 0.0223 & 3.50 & $I 0 \%$ \\
\hline
\end{tabular}

* Standard error of estimate of mean value.

morphological forms because it was found that, at certain times in the growth cycle, blastospores yielded a higher quantity of protein/mg dry wt than did mycelium (Table I). Thus the expression of enzyme activity/mg protein extracted would be invidious.

Measurement of protein. This was by the biuret method of Gornall, Bardswill \& David (1949) with bovine serum albumin (Fraction V, Sigma) as standard. Sugar phosphates, adenosine phosphates and pyridine nucleotides were obtained from Sigma Chemical Co., London; enzymes used in the assays were from Sigma Chemical Co. and Boehringer \& Sons, London; radiochemicals from Radiochemical Centre, Amersham, Buckinghamshire, and all other reagents from British Drug Houses Ltd, Poole, Dorset. 

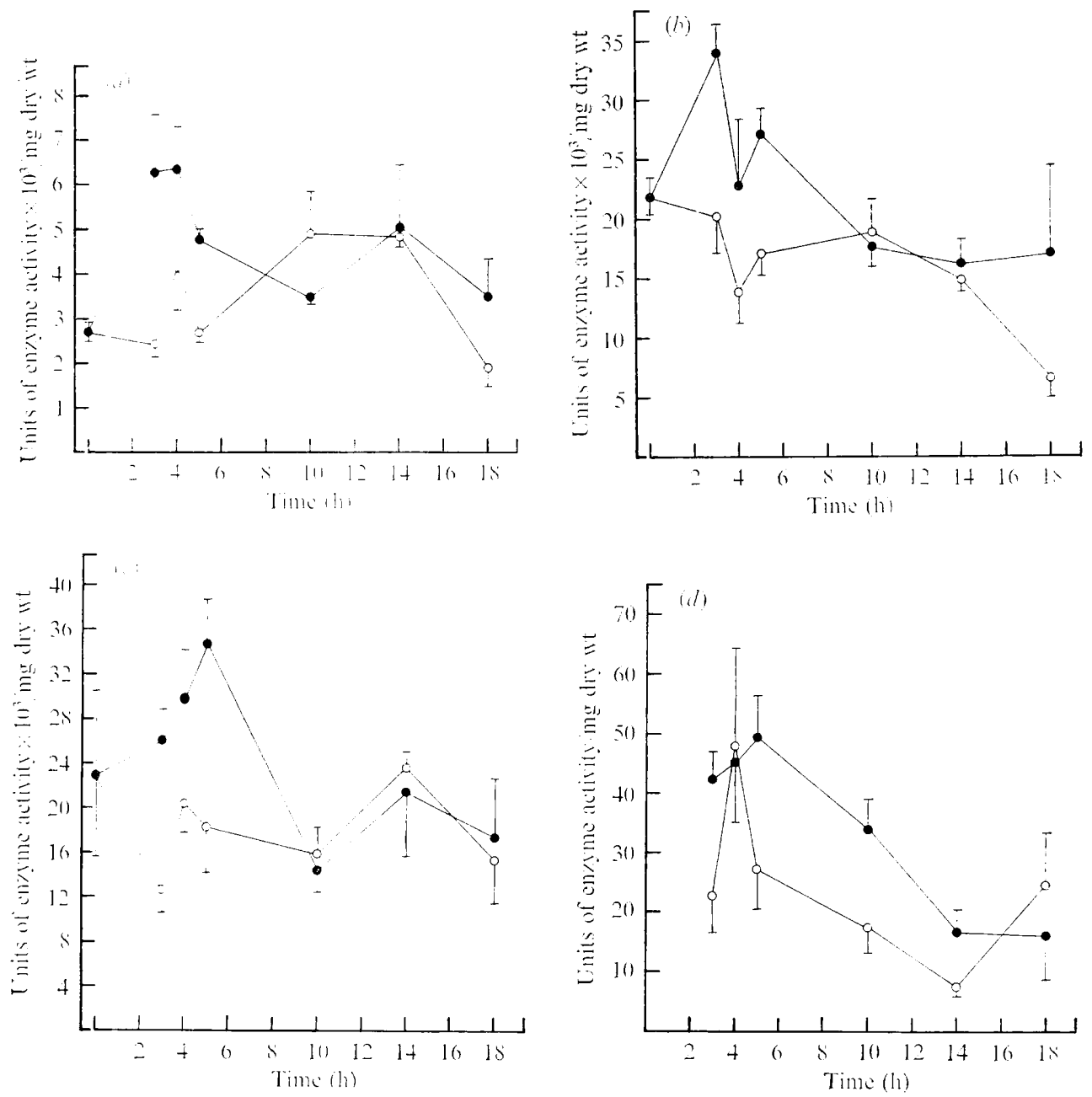

Fig. 2. Changes in enzyme activities with time. Growth of cells, preparation of extracts and enzyme assays at $\mathrm{pH} 6.45$ as described in Methods. $\mathrm{C}-\mathrm{O}$, Mycelium; -0 , blastospores. (a) Glucose-6-phosphate dehydrogenase; (b) 6-phosphogluconate dehydrogenase; $(c)$ phosphomannose isomerase; $(d)$ glutamine: D-fructose-6-phosphate aminotransferase. Each point represents the mean of at least four determinations, the bar indicates standard error of estimate of mean value (S.E.M.).

\section{RESULTS}

Proportion of mycelial and blastospore forms produced. Estimation at different times in the growth cycle showed that for all strains mycelium production was at a maximum at $4 \mathrm{~h}$, although the magnitude of this maximum varied from strain to strain (Fig. I). It thus appeared that total mycelium production was the sum of germ-tube formation and mycelium lengthening; this was maximal at this time and at later times there was a decrease in germtube formation from blastospores, when increase in the amount of mycelium present was only by apical extension of existing mycelial strands. This has been confirmed by time-lapse cine photomicrography when extensive lateral budding of blastospores from mycelium was 


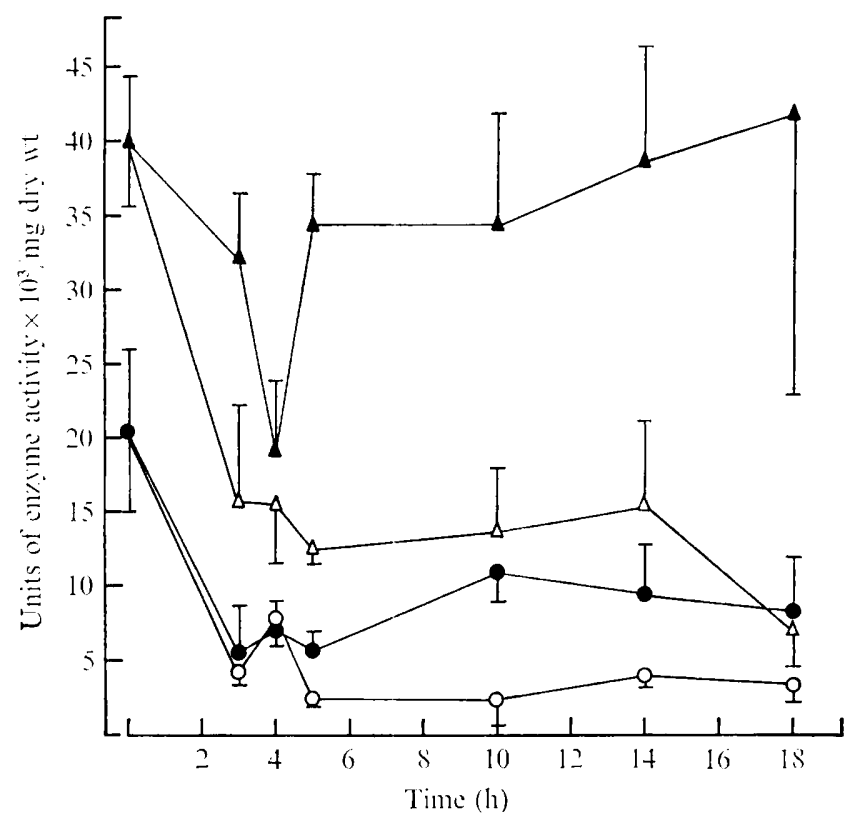

Fig. 3. Changes in phosphofructokinase activity with time. Growth of cells, preparation of extracts and enzyme assays as described in Methods. Each point represents the mean of at least four deter-

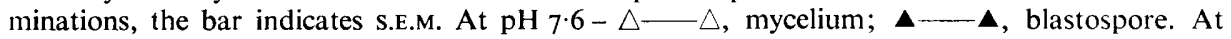
$\mathrm{pH} 6.45-\mathrm{O}-\mathrm{O}$, mycelium; - - , blastospore.

seen, but such blastospores did not form germ tubes. Thus enzyme activity at $4 \mathrm{~h}$ is of particular interest in relation to the maximal production of germ tubes at this time.

Enzyme activities. These have been determined in both growth forms at 3, 4, 5, 10, I4 and $\mathrm{I} 8 \mathrm{~h}$ after inoculation and in the cells used for inoculation, i.e. after growth on Sabouraud maltose agar at $30^{\circ} \mathrm{C}$ for $\mathrm{I} 8 \mathrm{~h}$ (Fig. 2, 3). The activities in mycelium were fairly uniform over the growth period examined, with some tendency to be less at $18 \mathrm{~h}$. The exception to this pattern was the L-glutamine-D-fructose-6-phosphate aminotransferase which showed a doubling in activity at $4 \mathrm{~h}$ (48 units/mg dry wt) as compared with 3 and $5 \mathrm{~h}$, then a fall to a low level ( 8 units/mg dry wt) at $\mathrm{I} 4 \mathrm{~h}$ followed by a rise at $\mathrm{I} 8 \mathrm{~h}$ to $25 \mathrm{units} / \mathrm{mg}$ dry wt, the only time at which the mycelial activity exceeded that of blastospores.

In blastospores the activities of glucose-6-phosphate dehydrogenase, 6-phosphogluconate dehydrogenase and phosphomannose isomerase were all higher than in mycelium in the 3 to $5 \mathrm{~h}$ period and progressively fell to approximately mycelial levels at later times, with the exception of mycelial glucose-6-phosphate dehydrogenase activity, which exceeded that of the blastospores at $\mathrm{I} o \mathrm{~h}$. The aminotransferase activity at $4 \mathrm{~h}$ was equal to that of the mycelial form. Phosphofructokinase activity was of a low order at all times, being almost the same in both forms at 3 and $4 \mathrm{~h}$ but the $4 \mathrm{~h}$ value for mycelium was the maximum found in this growth form; at all other times the activity in blastospores was approximately twice that found in mycelium. Phosphoglucose isomerase activity remained almost constant in both forms over the whole period.

Phosphofructokinase. This enzyme was examined in greater detail in view of its known role in controlling glycolytic activity and also its potential role in controlling the utilization of fructose-6-phosphate for cell-wall chitin and mannan synthesis. Of all the enzymes studied 


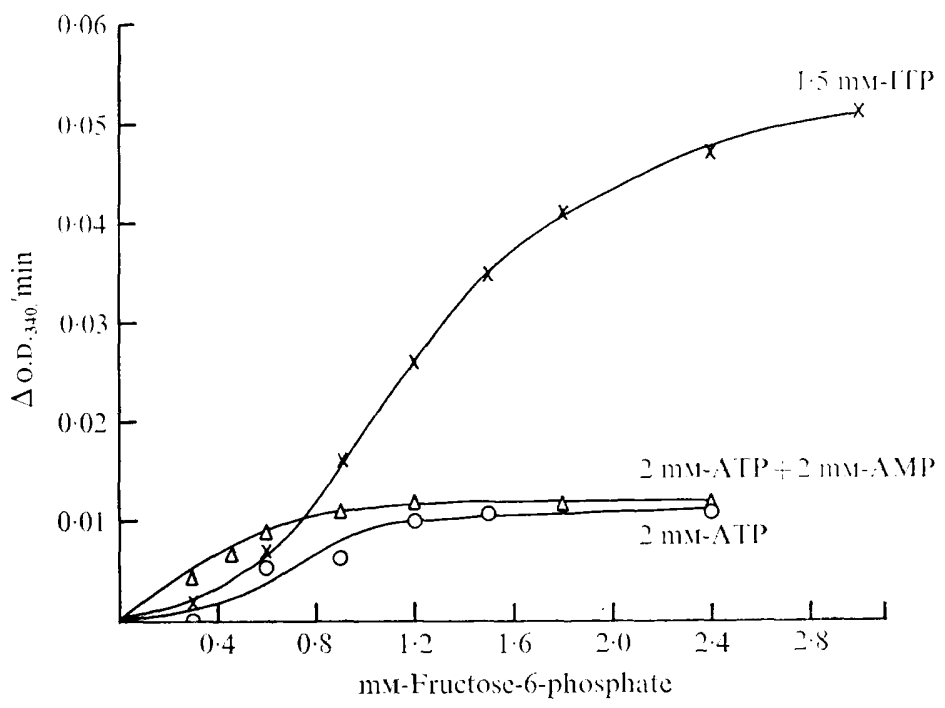

Fig. 4. Effect of nucleotide phosphates on phosphofructokinase activity in mycelium. Enzyme partially purified as described in Methods, final preparation contained $0.53 \mathrm{mg}$ protein/ml, $5 / \mathrm{gg}$ protein used in each assay.

this showed the greatest reduction in activity at $\mathrm{pH} 6.45$ as compared with $\mathrm{pH} 7.5$ (Fig. 3 ) and at the higher $\mathrm{pH}$ the lowest activity in the blastospores was after $4 \mathrm{~h}$ of growth. The enzyme was partially purified from both forms. The preparation from mycelium showed a $K_{m}$ value of ${ }_{1} \cdot 16 \mathrm{~mm}$ for fructose-6-phosphate and that from blastospores was $0.92 \mathrm{~mm}$, with inosinetriphosphate as phosphate donor. Both preparations showed inhibition of activity with ATP and reversal of the inhibition with adenosine monophosphate, as found with this enzyme from other sources. The determination of activity with increasing substrate concentration and with inosinetriphosphate as donor gave a sigmoid plot (Fig. 4), as with ATP, although activity was higher with the former, probably indicating some allosteric inhibition by inosine triphosphate as well as by ATP. This effect was found with the enzyme from both growth forms and the properties of the enzyme from these two sources were very similar.

L-Glutamine-D-fructose-6-phosphate aminotransferase. This enzyme may be a point of control for chitin synthesis. The results in Fig. $2(d)$ were obtained with concentrations of fructose-6-phosphate and glutamine giving maximum enzyme activity. Study of the relative enzyme activity shown by the ratio of the activity in the two forms at lower concentrations of fructose-6-phosphate showed greater activity for the mycelial enzyme. Fig. 5 shows that the ratio of mycelial: blastospore activity increased as the fructose-6-phosphate concentration was reduced at both high $(\mathrm{I} 2 \mu \mathrm{mol} / \mathrm{ml})$ and low $(\mathrm{I} \cdot 5 \mu \mathrm{mol} / \mathrm{ml})$ glutamine concentrations, with enzyme prepared after 4 or $\mathrm{I} 8 \mathrm{~h}$ of growth. That it was the fructose-6-phosphate concentration which was important was shown by the fact that similar experiments in which the glutamine concentration was varied while the fructose-6-phosphate remained at high concentration did not show variation in relative activity (Table 2). It is of interest that the highest relative activity was in $4 \mathrm{~h}$ mycelium with both substrates in low concentration, i.e. when the rate of development of mycelium was at its highest (Fig. I). In the intact organism the enzyme probably functioned at low substrate concentrations because extracts were found to contain concentrations of fructose-6-phosphate which were less than the lowest 


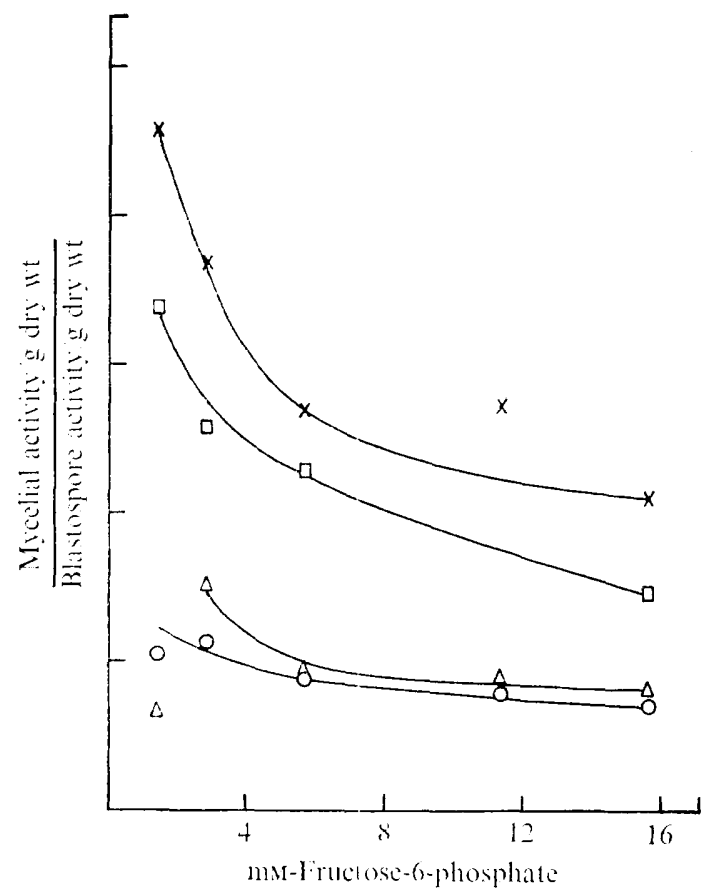

Fig. 5. Effect of fructose-6-phosphate concentration on relative activity of glutamine:D-fructose-6phosphate aminotransferase in mycelium and blastospores. Enzyme assay as in Methods except for variation in fructose-6-phosphate and glutamine concentrations. $\times-\cdots, 4 \mathrm{~h}$ cells, I. $5 \mathrm{~mm}$ glutamine; - $-4 \mathrm{~h}$ cells, $12 \mathrm{~mm}$-glutamine; $[-\square$, I $8 \mathrm{~h}$ cells, $12 \mathrm{~mm}$-glutamine; $\triangle-\triangle$, i 8 h cells, 1.5 mm-glutamine.

concentration used in these experiments (Table 3). This enzyme when isolated from animal tissues and Neurospora crassa has been shown to be subject to feedback inhibition by UDP$N$-acetyl-glucosamine but not when isolated from bacterial sources (Kornfeld, 1967). No such inhibition could be demonstrated with the enzyme prepared from either growth form of Candida albicans.

Intracellular concentration of metabolic intermediates. The studies with the aminotransferase and phosphofructokinase indicated the importance of the concentrations of the substrates and the adenosine phosphates in controlling enzyme activity. The concentrations of glucose-6-phosphate, fructose-6-phosphate, ATP, ADP and AMP were determined in the two growth forms after 4,10 and $18 \mathrm{~h}$ of growth (Table 3 ). The results show that the concentrations of glucose-6-phosphate, fructose-6-phosphate and ATP were at all times appreciably higher in mycelium than in blastospores. AMP concentration was virtually constant with time and was almost the same in the two forms. ADP concentration fell with time in mycelium but increased in blastospores. The effect of the adenosine phosphates on fructokinase activity was dependent upon the ratio ATP: ADP + AMP. This ratio was constant with time in mycelium at a value which was 2 to 4 times greater than that found in blastospores, which indicated that the enzyme would be more inhibited in mycelium than in blastospores. This was in agreement with the higher relative enzyme activity found in blastospores at $\mathrm{I} O$ and $\mathrm{I} 8 \mathrm{~h}$ (Fig. 3), but at earlier times some additional factor must have been involved because the recorded enzyme activities were equal in the two forms. The molar ratios of ATP:F6P were comparable with those found in mammalian tissues (Mansour, 
Table 2. Effect of glutamine concentration on L-glutamine-D-fructose-6-phosphate aminotransferase activity in mycelium and blastospore forms of Candida albicans

Assay conditions as in text except for variation of glutamine concentration.

\begin{tabular}{ccc} 
& \multicolumn{2}{c}{ Enzyme units/g dry wt mycelium } \\
\cline { 2 - 2 } $\begin{array}{c}\text { Glutamine } \\
\text { (m) }\end{array}$ & Enzyme units/g dry wt blastospores \\
& 4 h growth & I 8 h growth \\
$1.7 \mathrm{I}$ & $\mathrm{I} \cdot 24$ & $\mathrm{I} \cdot 5$ \\
3.42 & - & $\mathrm{I} \cdot 6$ \\
6.0 & $\mathrm{I} \cdot 02$ & $\mathrm{1} \cdot 8$ \\
12.0 & $\mathrm{I} \cdot 10$ & $\mathrm{I} \cdot 95$
\end{tabular}

Table 3. Cell content of hexose and adenosine phosphates in the morphological forms of Candida albicans

All concentrations in $\mu \mathrm{mol} / \mathrm{g}$ dry wt fungus and the mean of at least three determinations.

\begin{tabular}{|c|c|c|c|c|c|c|c|c|}
\hline \multirow[b]{2}{*}{$\begin{array}{l}\text { Growth } \\
\text { (h) }\end{array}$} & \multicolumn{3}{|c|}{ Glucose-6-phosphate } & \multicolumn{3}{|c|}{ Fructose-6-phosphate } & \multicolumn{2}{|c|}{ ATP } \\
\hline & \multicolumn{2}{|l|}{$\mathrm{M}$} & B & $\mathrm{M}$ & $-\ldots$ & & $\mathrm{M}$ & B \\
\hline 4 & \multicolumn{2}{|l|}{$2 \cdot 14$} & 0.500 & 0.702 & \multicolumn{2}{|c|}{0.104} & 6.95 & $I \cdot 46$ \\
\hline IO & \multirow{2}{*}{\multicolumn{2}{|c|}{$1 \cdot 73$}} & 0.317 & 0.209 & \multicolumn{2}{|c|}{0.054} & $4 \cdot 34$ & $2 \cdot 22$ \\
\hline I 8 & & & 0.077 & 0.370 & \multicolumn{2}{|c|}{0.048} & $5 \cdot 18$ & $1 \cdot 58$ \\
\hline & \multicolumn{2}{|c|}{ ADP } & & & \multicolumn{2}{|c|}{$\overline{\mathrm{ADP}}+\mathrm{AMP}$} & & \\
\hline (h) & $\mathbf{M}$ & B & M & B & M & B & M & B \\
\hline 4 & $12 \cdot 97$ & $4 \cdot 78$ & $5 \cdot 62$ & $6 \cdot 24$ & 0.373 & 0.132 & $9 \cdot 9$ & $14^{\circ} \mathrm{O}$ \\
\hline IO & $7 \cdot 86$ & 6.02 & $4 \cdot 46$ & $5 \cdot 60$ & 0.352 & $0.19 I$ & $20 \cdot 8$ & $4 \mathrm{I} \cdot \mathrm{O}$ \\
\hline I 8 & $9 \cdot 59$ & $11 \cdot 79$ & $5 \cdot 10$ & $5 \cdot 93$ & 0.354 & 0.089 & 14.0 & $33 \cdot 0$ \\
\hline
\end{tabular}

I963; Regen, Davis, Morgan \& Park, 1964) but quite different from those determined in sporulating and non-sporulating mycelium of Aspergillus niger by Smith \& ValenzuelaPerez (1971). However, the concentrations in the latter case were expressed as $\mu \mathrm{mol} / \mathrm{mg}$ protein, a basis which was not acceptable for comparing the growth forms in the present work and thus a direct comparison cannot be made. The higher molar ratios in the blastospores were a reflexion of the much lower concentrations of fructose-6-phosphate in this form.

Glucose metabolism through the HMP and Embden-Meyerhof-Parnas pathways. The extent of glucose metabolism through the main pathways for its degradation will give additional information about control over cellular activity. This has been determined by measuring the extent of ${ }^{14} \mathrm{CO}_{2}$ evolution from specifically labelled glucose over $\mathrm{I} 2 \mathrm{~h}$ by cells of both forms grown for 4, Io or $\mathrm{I} 8 \mathrm{~h}$. The results in Fig. 6 show marked differences in the fraction of glucose which was metabolized by the hexosemonophosphate (HMP) pathway. Thus the activities at 4 and $\mathrm{I} 8 \mathrm{~h}$ varied between $5 \%$ and $25 \%$ of the glucose metabolized, with the activity in blastospores greater than that in mycelium. At $\mathrm{I}$ o h the activities rose sharply to $48 \%$ (mycelium) and $40 \%$ (blastospore). 


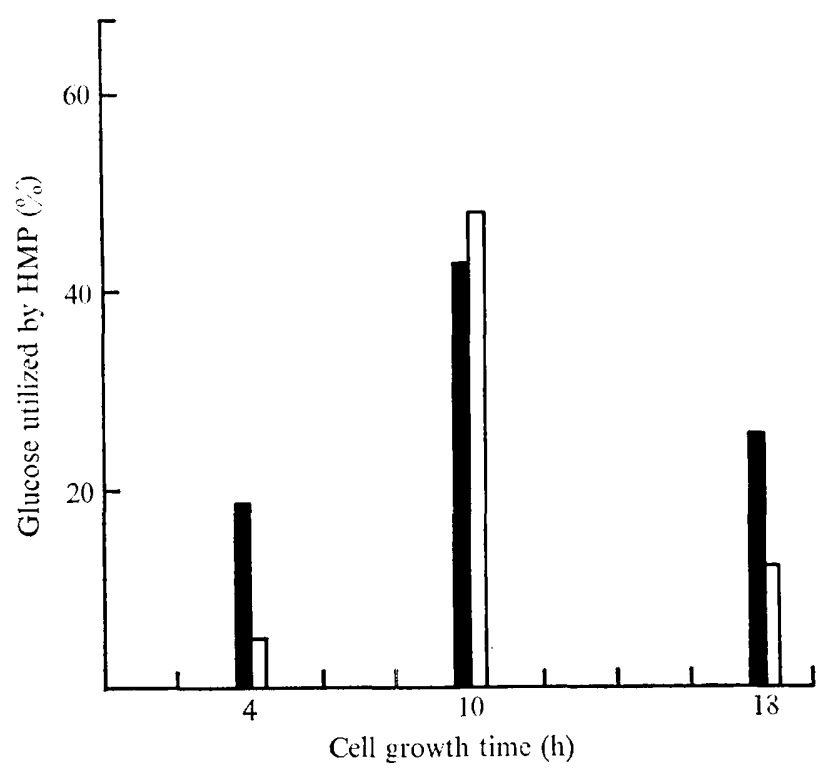

Fig. 6. Utilization of glucose by HMP pathway. $\square$, Mycelium; $\boldsymbol{\square}$, blastospores.

\section{DISCUSSION}

A comparison of the specific activities of enzymes in the dimorphic forms of an organism requires that the conditions for growth of the two forms should be as uniform as possible and that the assay conditions should be as close as possible to those in the intact cell. In the present study the growth medium was the same for both forms, the only difference being incubation temperature, namely $30{ }^{\circ} \mathrm{C}$ for blastospores and $40{ }^{\circ} \mathrm{C}$ for mycelium, and the intracellular $\mathrm{pH} 6.45$ has been used for enzyme assays. This value is the same as that for Saccharomyces cerevisiae (Polakis \& Bartley, 1965) and, while the $\mathrm{pH}$ may not necessarily be uniform throughout the cell, it is considered to be a reasonable value to use since the enzymes studied are all found in the soluble cytoplasm.

Previously demonstrated changes in polysaccharide content of the wall of mycelium and blastospores of Candida albicans suggest that enzyme activities associated with pathways leading to their synthesis may have a controlling influence on the morphological character. It is of interest to study such activities at three points in the growth cycle: (i) $4 \mathrm{~h}$ after inoculation, because this is the time of maximal development of mycelium from blastospores; (ii) Io to $14 \mathrm{~h}$ after inoculation where logarithmic growth is still occurring but blastospores appear committed to cell division rather than germ-tube formation, and mycelium is growing by apical extension with some development of side-budding to form blastospores; and (iii) I $8 \mathrm{~h}$ after inoculation when the culture has entered the stationary phase.

After $4 \mathrm{~h}$ the following findings indicated favourable conditions for the development of germ tubes: (i) phosphofructokinase activity was at its lowest level thus making fructose-6phosphate more readily available for conversion by the aminotransferase to glucosamine-6phosphate or by phosphomannose isomerase to mannose-6-phosphate; (ii) the former enzyme showed its maximum activity at this time and the latter was almost at its maximum; (iii) utilization of the HMP pathway was lowest, which again would tend to make substrate available for polysaccharide synthesis. This pathway is a major source of NADPH and it is 
of interest to note that high activity by this route would therefore yield a flow of electrons as was postulated by Nickerson (1963) to be required for the activity of a protein disulphide reductase which was active in promoting division by budding of blastospores. The low activity found in this pathway at $4 \mathrm{~h}$ was consistent with this hypothesis because germ-tube formation and mycelial development was maximal at this time; the higher activity in blastospores compared with mycelium was consistent with the fact that at this time approximately $50 \%$ of blastospores would not produce germ tubes. Thus cell division with its greater requirement for NADPH would be occurring to a significant extent. The high specific activity for glucose-6-phosphate dehydrogenase was not consistent with these findings but the extent of utilization of a pathway may not always correlate with the observed activity of a single, isolated enzyme. In mycelium at this time the continued development of this form was favoured by the low phosphofructokinase activity, the peak activity for the aminotransferase and the very low utilization of the HMP pathway.

At $\mathrm{IO} \mathrm{h}$ in blastospores there was a rise in phosphofructokinase activity, a fall in aminotransferase activity, and a considerable increase in the proportion of substrate being metabolized through the HMP pathway, all of which would favour cell division and blastospore formation. In mycelium at this time the observed development of blastospores by side-budding was indicated by the very large increase in the utilization of the HMP pathway, by the activity of glucose-6-phosphate dehydrogenase being higher than it was in the blastospores and in the decrease in the aminotransferase activity as compared with that found at $4 \mathrm{~h}$. The very low phosphofructokinase value would encourage diversion of substrate to chitin synthesis and thus to apical extension of the mycelium.

At $\mathrm{I} 8 \mathrm{~h}$ cell activity was largely directed to maintenance with a low rate of division of blastospores and extension of mycelium, and this was reflected in a generally lower activity, compared with that at earlier times, of all the enzymes examined except the mycelial aminotransferase. This enzyme showed an increase in activity to a level above that observed at 10 and $\mathrm{I} 4 \mathrm{~h}$ but not as high as that at $4 \mathrm{~h}$; this was in line with the clearly established higher concentration of chitin in mycelium of this age. The activity through the HMP pathway in blastospores was twice that found in mycelium, a fact which further supports the view that there is a higher requirement of NADPH for cell division than for mycelial extension.

An important factor in controlling hexose phosphate utilization is the activity of phosphofructokinase and its control by the adenosine phosphates. Mansour (1963) showed that the enzyme obtained from guinea-pig heart was much more susceptible to inhibition by ATP and to stimulation by ADP and AMP at pH 6.9 and at low fructose-6-phosphate concentrations than it was at its optimum $\mathrm{pH}(8 \cdot 2)$ and at higher substrate concentrations. The Candida enzyme has been shown to be much less active at the intracellular $\mathrm{pH} 6.45$ than at $\mathrm{pH} 7.5$ (Fig. 3) and concentrations of fructose-6-phosphate were low in both forms (Table 3). Thus phosphofructokinase was in a sensitive state for control by the adenosine phosphates; the differing concentrations of these which have been found provide evidence that this was a control point for utilization of fructose-6-phosphate with its activity being more repressed in mycelium than in blastospores. Thus there was an increased concentration of this substrate in mycelium and a probability that more would be used for chitin and mannan synthesis. That chitin synthesis may have been stimulated was also indicated by the increased relative activity of the mycelial aminotransferase at low fructose-6-phosphate concentrations (Fig. 5). It would be useful to determine the intracellular concentration of fructose-6-phosphate in vivo to compare with those used in these experiments. The dry wt of Candida blastospores centrifuged at $2000 \mathrm{~g}$ or of filtered mycelium was $25 \%$ of the wet wt after the material had been pressed between filter paper. Conway \& Downey (1950) showed that the intracellular 
water of a similar preparation of baker's yeast cells was $23 \%$ of this wet wt. Thus assuming a similar relationship for Candida the intracellular water is approximately $50 \%$ of the wet wt. Thus $4 \mathrm{~h}$ mycelium would contain $0.35 \mathrm{~mm}$-fructose-6-phosphate. This was the highest concentration found (Table 3) and the lowest concentration of fructose-6-phosphate used in the experiments with the aminotransferase was $\mathrm{I} .66 \mathrm{~mm}$. Thus in normal cells the concentration was usually below this value and mycelial aminotransferase would be relatively more active than the blastospore enzyme.

Thus differences have been found in enzyme activities associated with carbohydrate metabolism in the two morphological forms and at times associated with changes in morphology. These may be compared with the work of Smith, Valenzuela-Perez \& Ng (I97I) and Valenzuela-Perez \& Smith (I97I), who found that there were changes in activity of the glycolytic and HMP pathways in Aspergillus niger when grown on sporulating or nonsporulating media and that the differences were particularly prominent during the period preceding sporulation; they suggested that the glycolytic pathway is stimulated during sporulation. Brody (1970) found correlation between the concentration of NADPH and morphological changes in colonial mutants of Neurospora crassa and this was related to defective production of glucose-6-phosphate and 6-phosphogluconate dehydrogenase.

The recorded changes in enzyme activities, in utilization of glucose by catabolic pathways and in concentration of intermediates which are associated with morphological change were brought about by a change in growth temperature from 30 to $40{ }^{\circ} \mathrm{C}$. Comparison of the activity of the isolated enzymes concerned at these two temperatures showed the expected increases in activity at the higher temperature and no abrupt changes in activity which might have explained some of the observed results (unpublished results). The differences in concentration of hexose and adenosine phosphates between mycelium and blastospores and their effects on the activity of certain enzymes affords a partial explanation of changes in the control mechanisms which result in changed cell morphology.

We gratefully acknowledge maintenance grants to M.R.H. and R.B. from the Wellcome Trust and to F.C.O. from the Medical Research Council, and grants for materials from both bodies. We also thank Dr D. G. Herries for advice on the kinetics of phosphofructokinase action and Mrs Ann Mason for skilled assistance.

\section{REFERENCES}

Adam, H. (1963). Methods of Enzymatic Analysis, ist edn, p. 573. New York: Academic Press.

BARTNICKI-GARCIA, S. ( 1968 ). Control of dimorphism in Mucor by hexoses: inhibition of hyphal morphogenesis. Journal of Bacteriology 96, $1586-$ I 594.

Bartnicki-Garcia, S. \& Nickerson, W. J. (I962). Induction of yeastlike development in Mucor rouxii. Journal of Bacteriology 84, 829-840.

Brody, S. (1970). Correlation between NADPH levels and morphological changes in Neurospora crassa. Journal of Bacteriology ror, 802-807.

Carbonell, L. M. \& Kanetsuna, F. (1966). Enzymes in glycolysis and the citric acid cycle in the yeast and mycelial forms of Paracoccidioides brasiliensis. Journal of Bacteriology 92, $1315-1320$.

Carbonell, L. M. \& Kanetsuna, F. (1970). Cell wall glucans of the yeast and mycelial forms of Paracoccidioides brasiliensis. Journal of Bacteriology Ior, 675-680.

Chattaway, F. W., Holmes, M. R. \& Barlow, A. J. E. (I968). Cell wall composition of mycelial and blastospore forms of Candida albicans. Journal of General Microbiology 51, 367-376.

Conway, E. J. \& Downey, M. (1950). An outer metabolic region of the yeast cell. Biochemical Journal 47, $347-355$.

Domer, J. E., Hamilton, J. G. \& Harkin, J. C. (1967). Comparative study of the cell walls of the yeastlike and mycelial phases of Histoplasma capsulatum. Journal of Bacteriology 94, 466-474. 
Ghosh, S., Blumenthal, H. J., Davidson, E. \& Roseman, S. (1960). Glucosamine metabolism. V. Enzymatic synthesis of glucosamine-6-phosphate. Journal of Biological Chemistry 235, 1265-1 273.

Gornall, A. G., Bardswill, C. J. \& David, H. M. (I949). Determination of serum proteins by means of the biuret reaction. Journal of Biological Chemistry $\mathbf{1 7 7}, 75 \mathrm{I}$.

Gracy, R. W. \& Noltmann, E. A. (1968). Studies on phosphomannose isomerase. I. Isolation, homogeneity measurements and determination of some physical properties. Journal of Biological Chemistry 243, 3I 6 I -3 I 68.

Hohorst, H.-J. (1963). Methods of Enzymatic Analysis, Ist edn, p. I34. Edited by H.-U. Bergmeyer. New York: Academic Press.

Kanetsuna, F., Carbonell, L. M., Moreno, R. E. \& Rodriguez, J. (1969). Cell wall composition of the yeast and mycelial forms of Paracoccidioides brasiliensis. Journal of Bacteriology 97, 1036-104I.

KORNFELD, R. ( 1967). Studies on L-glutamine-D-fructose-6-phosphate amidotransferase. Feedback inhibition by uridine diphosphate- $N$-acetylglucosamine. Journal of Biological Chemistry 242, 3I 35-3I4I.

Lamprecht, W. \& Trautschold, I. (1963). Methods of Enzymatic Analysis, Ist edn, p. 543. Edited by H.-U. Bergmeyer. New York: Academic Press.

Lindell, T. J. \& Stellwagen, E. (1968). Purification and properties of phosphofructokinase from yeast. Journal of Biological Chemistry 243, 907-9 2.

Mansour, T.E. (1963). Studies on heart phosphofructokinase: purification, inhibition and activation. Journal of Biological Chemistry 238, 2285-2292.

Mardon, D., Balish, E. \& Phillips, A. W. (1969). Control of dimorphism in a biochemical variant of Candida albicans. Journal of Bacteriology roo, $70 \mathrm{I}-707$.

Nickerson, W. J. (1963). Symposium on biochemical bases of morphogenesis in fungi. IV. Molecular bases of form in yeasts. Bacteriological Review 27, 305-324.

Polakis, E. S. \& Bartley, W. (1965). Changes in the enzyme activities of Saccharomyces cerevisiae during aerobic growth on different carbon sources. Biochemical Journal 97, 284-297.

RACKER, E. (1947). Spectrophotometric measurement of hexokinase and phosphohexokinase activity. Journal of Biological Chemistry $\mathbf{1 6 7}, 843-854$.

Regen, D. M., Davis, W. W., Morgan, H. E. \& Park, C. R. (1964). The regulation of hexokinase and phosphofructokinase activity in heart muscle. Journal of Biological Chemistry 239, 43-49.

Smith, J. E. \& Valenzuela-Perez, J. (I97I). Changes in intracellular concentrations of glycolytic intermediates and adenosine phosphates during growth cycle of Aspergillus niger. Transactions of the British Mycological Society 57, I03-I IO.

Smith, J. E., Valenzuela-Perez, J. \& NG, W. S. (I97I). Changes in the activities of enzymes of the EmbdenMeyerhof-Parnas and pentose phosphate pathways during the growth cycle of Aspergillus niger. Transactions of the British Mycological Society 57, 93-IOI.

Valenzuela-Perez, J. \& Smith, J. E. (I97I). Role of glycolysis in sporulation of Aspergillus niger in submerged culture. Transactions of the British Mycological Society 57, I I I-I I9.

WAdDELl, W. J. \& Butler, T. C. (1959). Calculation of intracellular pH from the distribution of 5,5dimethyl-2,4-oxazolidinedione (DMO). Application to skeletal muscle of the dog. Journal of Clinical Investigation $38,720-729$.

WANG, C. H. (1972). Methods in Microbiology, vol. 6B, Ist edn, chapter VII. Edited by J. R. Norris and D. W. Ribbons. London: Academic Press. 